\title{
Impact of Particulate Matter Emissions from Ship Power Plants on the Port City Environment
}

\author{
Elena V. Grigorieva ${ }^{1}$, Valery V. Chernyshev ${ }^{2 *}$, Sergei V. Kulichkov ${ }^{1}$ and Larisa V. \\ Andreeva $^{2}$ \\ ${ }^{1}$ Far Eastern State Technical Fisheries University, Engineering Disciplines Department, 52 B Lugovaya \\ Str., Vladivostok 690087, Russia \\ ${ }^{2}$ Far Eastern Federal University, Polytechnic Institute, Department of Oil, Gas and Petrochemical \\ Industry, Campus 10 Ajax Bay, Russky Island, Vladivostok 690922, Russia
}

\begin{abstract}
The paper deals with one of the methods for assessing anthropogenic impact of the operation of ship power plants in port areas on the environment. The measurement of mass concentration of particulate matters (PM) in the open air was carried out during summer and winter in eight points of the city that were selected depending on the conditions of orographic characteristics of the area. Moreover, vessel traffic in coastal waters was assessed and information on the number and type of vessels was collected. Based on the data obtained, the total PM volume emitted with exhaust gases from ship power plants in the port areas during a year was calculated.
\end{abstract}

\section{Introduction}

Air pollution level in many cities of the world goes beyond the level recommended by the World Health Organization [1]. In large industrial centers the key sources of PM in atmosphere are industrial and energy enterprises as well as automobile transport $[2,3]$. But in port cities water transport is yet another source of PM pollution, and it should be taken into account, especially when monitoring pollution with fine particles $[4,5]$.

\section{Literature overview}

Air pollution is mainly caused by multiple anthropogenic emission sources, such as industrial activity, populated area as well as marine, railway, air and automobile transport. However, majority of studies in Vladivostok is focused on ground emission sources. The studies of Golokhvast et al. (2017) [6], Kirichenko et al. (2018) [7] and Chernyshev et al. (2019) [8] are good examples. In recent years no studies of the impact of exhaust gases from ship power plants on the environment in the ports of the region have been carried out, although the commercial port of Vladivostok is a large port in the Russian Far East with significant growth rates (about 39\%) [9].

Over past two decades the studies of the environmental pollution by emissions of particles from different types of vehicles have been carried out in many parts of the world $[10,11,12]$ : on dynamometer stands based on the cycles of their movement [10, 12]; in real traffic conditions on the roads, in motorway tunnels [9, 13] or near such motorways [11]. All studies are based on the method for calculating emission factors of toxic substances in vehicle exhaust gases that can be used to determine their volume based only on the characteristics of their source [11].

\footnotetext{
* Corresponding author: chernyshev.vv@dvfu.ru
} 
Jones et al. [11] calculated and proposed in their work the emission factors for particulate matters based on their number per one vehicle per kilometer (Table 1).

Table 1. Emission factors for PM2.5 and PM10 [11]

\begin{tabular}{|c|c|c|c|c|c|}
\hline Pollutant & \multirow{2}{*}{$\begin{array}{c}\text { Measurement } \\
\text { units }\end{array}$} & \multicolumn{2}{|c|}{ Heavy vehicle } & \multicolumn{2}{c|}{ Light-duty vehicle } \\
\cline { 3 - 6 } & & $\begin{array}{c}\text { Emission } \\
\text { coefficient }\end{array}$ & $\begin{array}{c}\text { Standard } \\
\text { deviation }\end{array}$ & $\begin{array}{c}\text { Emission } \\
\text { coefficient }\end{array}$ & $\begin{array}{c}\text { Standard } \\
\text { deviation }\end{array}$ \\
\hline PM2.5 & g.veh ${ }^{-1} \cdot \mathrm{km}^{-1}$ & 0.179 & 0.022 & 0.010 & 0.004 \\
\hline PM10 & g.veh $\mathrm{km}^{-1}$ & 0.370 & 0.032 & 0.033 & 0.006 \\
\hline
\end{tabular}

Assuming that other pollutants dissipate from their point of release to the sampling points in the same way as $\mathrm{NO}_{\mathrm{x}}$ :

where

$$
f\left\{E_{\mathrm{O}(\text { pollutant })} \rightarrow \mathrm{X}_{(\text {pollutant })}\right\}=f\left\{E_{\mathrm{O}\left(N O_{x}\right)} \rightarrow \mathrm{X}_{\left(N O_{x}\right)}\right\}
$$

$\mathrm{E}_{\mathrm{O} \text { (pollutant) }}-$ emission per kilometer for the total number of vehicles passing per hour,

$\mathrm{X}_{\text {(pollutant) }}$ - concentration of every pollutant on the roads,

$\mathrm{E}_{\mathrm{O}(\mathrm{NOx})}-\mathrm{NO}_{\mathrm{x}}$ emission for all vehicles passing the sampling points,

$\mathrm{X}_{(\mathrm{NOx})}-\mathrm{NO}_{\mathrm{x}}$ concentrations on the roads.

Having set up an equation of linear regression, A.M. Jones et al. [9] determined the relation between $\mathrm{E}_{\mathrm{O}(\mathrm{NOx})}$ and $\mathrm{X}_{(\mathrm{NOx})}$ as follows:

$$
\mathrm{E}_{\mathrm{O}(\mathrm{NOx})}=12.48( \pm 0.55) * \mathrm{X}_{(\mathrm{NOx})}+69.50( \pm 190.56) \mathrm{gkm}^{-1}(2)
$$

where: $\mathrm{X}_{\text {(NOx) }}\left(\right.$ in $\mathrm{mgm}^{-3}$ ) means standard deviations of the factors (given in brackets). So, the connection between total emission of any pollutant and its concentration at the measurement point and at the background section may be determined as follows:

$$
\mathrm{EO}_{\mathrm{O}(\text { pollutant })}=12.48( \pm 0.55) * \mathrm{X}_{(\text {pollutant })}+69.50( \pm 190.56) \mathrm{gkm}^{-1}
$$

Or, if ignoring the influence of other secondary sources -

$$
\mathrm{E}_{\mathrm{O}(\text { pollutant })}=12.48( \pm 0.55) * \mathrm{X}_{\text {(pollutant) }}
$$

The measurements were taken by a handheld particle counter TSI Aerotrack 9306 V2 (measurement range from 0.3 to $10 \mu \mathrm{m}$ ) during eight summer weeks from July 2 till September 2, 2018 and during eight winter weeks from January 8 till March 4, 2018. On average, 50 measurements were made per day with an interval of $20 \mathrm{~min}$. The time of one measurement was 1 minute and the volume of the measured air sample comprised 2.8 liters.

The information about vessels was taken from https://www.marinetraffic.com/ for two periods: from July 29 till August 28 and from November 15 till December 15. Besides the number of ships specified in Tables 2 and 3, the average gross tonnage of each type of vessel was collected and shown in Table 4. 
Table 2. Information about the number of vessels in the port area of Vladivostok city in 2019.

\begin{tabular}{|c|c|c|c|}
\hline \multirow{2}{*}{ Vessel category } & \multicolumn{2}{|c|}{ Periods } & \multirow{2}{*}{$\begin{array}{c}\text { Average } \\
\text { value }\end{array}$} \\
\cline { 2 - 3 } & $\begin{array}{c}\text { August 14- August } \\
\mathbf{2 7}\end{array}$ & $\begin{array}{c}\text { December 1 - } \\
\text { December 14 }\end{array}$ & \\
\hline Passenger & 8.6 & 4.6 & 6.6 \\
\hline Bulk Carriers & - & - & 1.5 \\
\hline Containers & - & - & 2.2 \\
\hline Consolidated cargo & - & - & 4.0 \\
\hline RO-RO vessels & - & - & 1.8 \\
\hline Tankers & 6.1 & 1.5 & 7.1 \\
\hline Tugs & 2.8 & 1.3 & 2.1 \\
\hline Fishing vessels & 2.8 & 10.9 & 2.0 \\
\hline Other & 10.8 & & 10.9 \\
\hline
\end{tabular}

Table 3. Average number of arriving and departing vessels.

\begin{tabular}{|c|c|c|c|}
\hline \multirow{2}{*}{ Event } & \multicolumn{2}{|c|}{ Periods } & \multirow{2}{*}{$\begin{array}{c}\text { Average } \\
\text { value }\end{array}$} \\
\cline { 2 - 4 } & July 29-August 28 & November 15- December 15 & 40.8 \\
\hline Arrivals per day & 45.9 & 35.7 & 39.8 \\
\hline Departures per day & 44.8 & 34.7 & 1.8 \\
\hline Arrivals per hour & 2.06 & 1.49 & 1.7 \\
\hline Departures per hour & 2.0 & 1.45 & \\
\hline
\end{tabular}

Table 4. Relation between engine power and gross tonnage of a vessel.

\begin{tabular}{|c|c|c|c|}
\hline Vessel category & $\begin{array}{c}\text { Relation between the } \\
\text { power of main engine } \\
\text { and gross tonnage of a } \\
\text { vessel [12] }\end{array}$ & $\begin{array}{c}\text { Relation between the power } \\
\text { of main and auxiliary } \\
\text { engines [12] }\end{array}$ & $\begin{array}{c}\text { Average } \\
\text { gross } \\
\text { tonnage }\end{array}$ \\
\hline Tankers & 14.75 * $^{*} \mathrm{GT}^{0.6082}$ & 0.30 & 1,909 \\
\hline Bulk Carriers & $35.912 * \mathrm{GT}^{0.5276}$ & 0.30 & 19,572 \\
\hline Containers & $2.9165 * \mathrm{GT}^{0.8719}$ & 0.25 & 6,335 \\
\hline $\begin{array}{c}\text { Consolidated } \\
\text { cargo }\end{array}$ & $5.56482 * \mathrm{GT}^{0.7425}$ & 0.23 & 4,821 \\
\hline RO-RO vessels & $164.578 * \mathrm{GT}^{0.4350}$ & 0.24 & 14,127 \\
\hline Passenger & $9.55078 * \mathrm{GT}^{0.7570}$ & 0.16 & 718 \\
\hline Fishing vessels & $9.75891 * \mathrm{GT}^{0.7527}$ & 0.39 & 1,353 \\
\hline Other & $59.049 * \mathrm{GT}^{0.5485}$ & 0.35 & 4,636 \\
\hline Tugs & $54.2171 * \mathrm{GT}^{0.6420}$ & 0.10 & 1,046 \\
\hline
\end{tabular}

Table 5. Average power of main and auxiliary engines.

\begin{tabular}{|c|c|c|}
\hline Vessel category & $\begin{array}{c}\text { Average power of the main } \\
\text { engine (kW) }\end{array}$ & $\begin{array}{c}\text { Average power of the auxiliary } \\
\text { engine (kW) }\end{array}$ \\
\hline Tankers & $1,977.1$ & 593.1 \\
\hline Bulk Carriers & $7,248.2$ & $2,174.5$ \\
\hline Containers & $4,571.9$ & $1,143.0$ \\
\hline Consolidated cargo & $3,255.4$ & 748.7 \\
\hline
\end{tabular}




\begin{tabular}{|c|c|c|}
\hline Vessel category & $\begin{array}{c}\text { Average power of the main } \\
\text { engine (kW) }\end{array}$ & $\begin{array}{c}\text { Average power of the auxiliary } \\
\text { engine (kW) }\end{array}$ \\
\hline RO-RO vessels & $9,948.6$ & $2,387.7$ \\
\hline Passenger & 598.9 & 95.8 \\
\hline Other & $3,875.7$ & $1,356.5$ \\
\hline Tugs & $3,581.9$ & 358.2 \\
\hline Fishing vessels & $1,505.4$ & 587.1 \\
\hline
\end{tabular}

Estimation of the average power of main and auxiliary engines of the vessels is based upon relation between the power of main engine and gross tonnage of the vessels as well as on the relation between the power of main and auxiliary engines. The results are given in tables 3 and 5.

\section{The method for estimation of particle emissions by vessels}

Average emission from main and auxiliary engines is calculated according to the following formula [14].

where

$$
\mathrm{E}=\mathrm{MCR} \times \mathrm{LF} \times \mathrm{EF} \times \mathrm{FCF} \times \mathrm{LLA}
$$

E - speed of emission from the engine $(\mathrm{g} / \mathrm{h})$;

MCR - maximum continuous rating (kW) (given in table 4);

LF - load factors (without units) (given in table 5, 6);

$\mathrm{EF}$ - emission coefficient $(\mathrm{g} / \mathrm{kWh})$,

FCF - fuel correction factor (without measurement units);

LLA - low load adjustment (without measurement units);

Table 6. Auxiliary engine load factor allowances [15]

\begin{tabular}{|c|c|c|c|}
\hline Vessel category & Cruising mode & Maneuver mode & Hotel mode \\
\hline Bulk Carriers & 0.17 & 0.45 & 0.10 \\
\hline Containers & 0.13 & 0.48 & 0.19 \\
\hline Passenger & 0.80 & 0.80 & 0.64 \\
\hline Consolidated cargo & 0.17 & 0.45 & 0.22 \\
\hline Tugs & 0.17 & 0.45 & 0.22 \\
\hline RO-RO vessels & 0.15 & 0.45 & 0.26 \\
\hline Refrigerators & 0.20 & 0.67 & 0.32 \\
\hline Tankers & 0.24 & 0.33 & 0.26 \\
\hline Other & 0.17 & 0.45 & 0.22 \\
\hline
\end{tabular}

Table 7. Main engine load factor allowances [16]

\begin{tabular}{|c|c|}
\hline Operation mode & Main engine load \\
\hline Cruising mode & 80 \\
\hline Maneuver mode & 20 \\
\hline Hotel mode & 20 \\
\hline
\end{tabular}

Emission factors for engines on heavy diesel fuel with average sulfur content of $2.7 \%$ comprise $1.2 \mathrm{~g} / \mathrm{kWh}$ for PM2.5 and $1.5 \mathrm{~g} / \mathrm{kWh}$ for PM10 [14].

When vessels navigate in port areas, the main engines are usually operated under very low load. In general, diesel engines are not as efficient when operating under low loads. For 
main engines operating under load not exceeding 20 percent, decrease in engine efficiency and increase of emission factors are taken into account by using correction factors as a load function (given in table 7). Adjustment for auxiliary engines under low load is not carried out as far as they always operate under optimum loads [16].

Table 8. Low load adjustment for emission coefficients

\begin{tabular}{|c|c|c|c|c|c|c|c|c|c|}
\hline Load (\%) & $\mathbf{2}$ & $\mathbf{3}$ & $\mathbf{4}$ & $\mathbf{5}$ & $\mathbf{6}$ & $\mathbf{7}$ & $\mathbf{8}$ & $\mathbf{9}$ & $\mathbf{1 0}$ \\
\hline PM & 7.29 & 4.33 & 3.09 & 2.44 & 2.04 & 1.79 & 1.61 & 1.48 & 1.38 \\
\hline
\end{tabular}

\begin{tabular}{|c|c|c|c|c|c|c|c|c|c|c|}
\hline Load (\%) & $\mathbf{1 1}$ & $\mathbf{1 2}$ & $\mathbf{1 3}$ & $\mathbf{1 4}$ & $\mathbf{1 5}$ & $\mathbf{1 6}$ & $\mathbf{1 7}$ & $\mathbf{1 8}$ & $\mathbf{1 9}$ & $\mathbf{2 0}$ \\
\hline $\mathrm{PM}$ & 1.30 & 1.24 & 1.19 & 1.15 & 1.11 & 1.08 & 1.06 & 1.04 & 1.02 & 1 \\
\hline
\end{tabular}

Sulfur content in fuel affects particles emissions from engines. That's why fuel correction factors are used for calculating emissions when the actual fuel used differes from $2.7 \% \mathrm{~S}$ fuel. Such fuel correction factors are represented in Table 9.

Table 9. Fuel correction factors (FCR)

\begin{tabular}{|c|c|c|c|c|c|}
\hline Actual fuel & HFO & MDO & MDO/MGO & MDO/MGO & MDO/MGO \\
\hline Sulfur content (\%) & 1.5 & 1.5 & 0.50 & 0.2 & 0.1 \\
\hline FCF (PM) & 0.82 & 0.47 & 0.25 & 0.19 & 0.17 \\
\hline
\end{tabular}

Calculation of total annual emission of PM2.5 and PM10 is based on the following formula:

$$
T E=\left[a_{1} \times\left(E R_{1}+E R_{2}\right)+\sum_{i=1}^{b}\left(a_{2} \times E R_{3}\right)\right] \times 24 \times 365 \times 10^{6}
$$

where:

TE - total volume of particle emissions per year $(\mathrm{t} / \mathrm{y})$;

$\mathrm{a}_{1}=3.5$ : average number of vessels arriving and departing per hour. This parameter is obtained from table $2 b$;

$\mathrm{ER}_{1}$ - average rate of emissions from main engines when vessels operate in maneuvering mode $(\mathrm{g} / \mathrm{h})$. This parameter is calculated according to formula 3 ;

$\mathrm{ER}_{2}$ - average rate of emissions from auxiliary engines when vessels operate in maneuvering mode $(\mathrm{g} / \mathrm{h})$. This parameter is calculated according to formula 4 ;

$\mathrm{b}=8$ - number of types of vessels;

$\mathrm{a}_{2}$ average number of vessels of each type. This parameter can be found in table $2 \mathrm{a}$

$\mathrm{ER}_{3}$ - average rate of particle emissions from auxiliary engines when vessels operate in hotel mode $(\mathrm{g} / \mathrm{h})$. This parameter can be found in table 9 .

Parameters $\mathrm{ER}_{1}$ and $\mathrm{ER}_{2}$ are calculated according to the following formula:

where:

$$
\begin{gathered}
E R_{1}=\frac{\sum_{i=1}^{b}\left(a_{2} \times E R_{4}\right)}{\sum_{i=1}^{b} a_{2}} \\
E R_{2}=\frac{\sum_{i=1}^{b}\left(a_{2} \times E R_{5}\right)}{\sum_{i=1}^{b} a_{2}}
\end{gathered}
$$

$\mathrm{ER}_{4}$ : average rate of emissions from main engines when vessels operate in maneuvering mode $(\mathrm{g} / \mathrm{h})$. This parameter is given in Table 10 ;

$\mathrm{ER}_{5}$ : average rate of emissions from auxiliary engines when vessels operate in maneuvering mode $(\mathrm{g} / \mathrm{h})$. This parameter is given in Table 10 .

Table 10. Average level of emissions from main and auxiliary engines with MDO 1.5. 


\begin{tabular}{|c|c|c|c|c|c|c|}
\hline Vessel category & \multicolumn{2}{|c|}{$\begin{array}{c}\text { Main engine } \\
\text { emissions level } \\
\text { (g/h) under 20\% } \\
\text { load. }\end{array}$} & \multicolumn{2}{|c|}{$\begin{array}{c}\text { Speed of emission from } \\
\text { auxiliary engines under } \\
\text { maneuvering load (g/h) }\end{array}$} & \multicolumn{2}{c|}{$\begin{array}{c}\text { Speed of emission } \\
\text { from auxiliary } \\
\text { engines under hotel } \\
\text { load (g/h) }\end{array}$} \\
\cline { 2 - 7 } & $\mathbf{P M 2 . 5}$ & $\mathbf{P M 1 0}$ & $\mathbf{P M 2 . 5}$ & $\mathbf{P M 1 0}$ & $\mathbf{P M 2 . 5}$ & $\mathbf{P M 1 0}$ \\
\hline Tankers & 223.0 & 278.8 & 110.4 & 138.0 & 87.0 & 108.7 \\
\hline Bulk Carriers & 817.6 & $1,022.0$ & 551.9 & 689.8 & 122.6 & 153.3 \\
\hline Containers & 515.7 & 644.6 & 290.1 & 362.6 & 122.5 & 153.1 \\
\hline Consolidated cargo & 367.2 & 459.0 & 190.0 & 237.5 & 92.9 & 116.1 \\
\hline RO-RO vessels & $1,122.2$ & $1,402.8$ & 606.0 & 757.5 & 350.1 & 437.7 \\
\hline Passenger & 67.6 & 84.4 & 43.2 & 54.0 & 34.6 & 43.2 \\
\hline Other & 437.2 & 546.5 & 512.6 & 640.7 & 244.8 & 306.0 \\
\hline Tugs & 404.0 & 505.0 & 90.9 & 113.6 & 44.4 & 55.6 \\
\hline
\end{tabular}

Emission factors for marine engines are represented in table 9. There is a considerable difference in emission factors of main engines. Main engine of a Ro-Ro vessel has the highest emission factor: $1,122 \mathrm{~g} / \mathrm{h}$ and 1,403 $\mathrm{g} / \mathrm{h}$ for PM2.5 and PM10 respectively. In contrast, main engine of a passenger vessel has the lowest emission factor of $68 \mathrm{~g} / \mathrm{h}$ for PM2.5 and $84 \mathrm{~g} / \mathrm{h}$ for PM10. A similar tendency is observed in the rate of emissions from auxiliary engines both in maneuvering and hotel modes. Emission factor greatly depends on the type of engine, fuel, operation mode of the engines. Emission factor for engines operating on 0.5 and $0.1 \%$ sulfur fuel were calculated in a similar way, but the results are not given in this paper.

The total mass of particulate matters emitted from marine engines in the port area of Vladivostok city is represented in figure 1 . When all vessels operated on $1.5 \% \mathrm{~S}$ MDO, the total mass of PM2.5 and PM10 emitted per year comprised 66.2 and 82.7 tons per year respectively. However, when sulfur content in fuel decreased from $1.5 \%$ to $0.5 \%$ and $0.1 \%$, the total mass of particles decreased by $47 \%$ and $67 \%$ respectively. It is obvious that particle emission greatly depends on sulfur content in fuel.

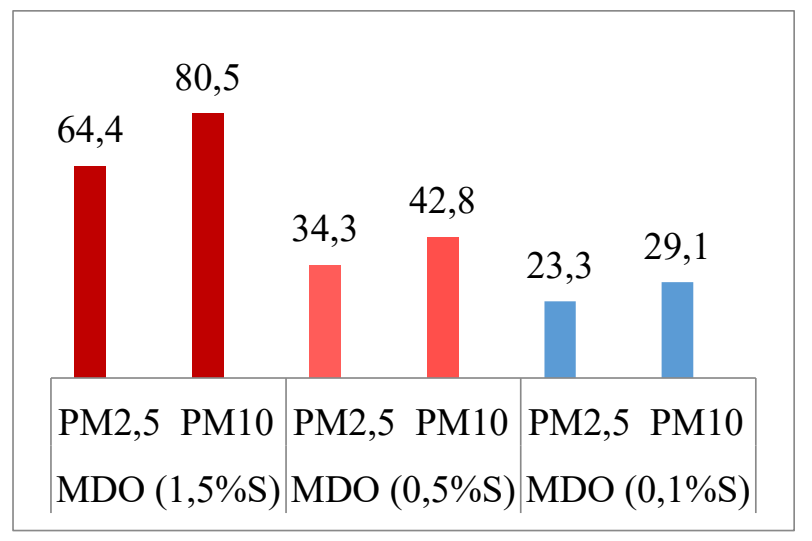

Fig. 1. Total mass of PM2.5 and PM10 emitted from marine engine in the area of Vladivostok city, tons per year.

Average concentration of PM2.5 in all measurement points is within the limits of the WHO and Russia standards (as shown in tables 10,11). In contrast, an average concentration of PM10 in majority of measurement points is approximately 1.5 times greater than the WHO permissible level. In particular, concentration in the area of funicular is almost three times larger. However, PM10 concentration is still within permissible limits for Russia, except for 
PM10 concentration in the funicular area. Airborne particulate matters have such negative effects on public health as an increased risk of untimely death from heart and lung diseases and acute exacerbation of respiratory diseases. It was demonstrated that the death rate connected with a short-term exposure of fine particles will be increased by $0.6-1 \%$ for adults and by $1.66 \%$ for children, if the concentration of particles in the environment is increased by $10 \mu \mathrm{g} / \mathrm{m} 3$ [16]. Lozovskaya et al. pointed out that between 2000 and 2016 air pollution caused an increase in the primary incidence with respiratory diseases among adult population by $8.5 \%$ in the Primorsky region and by $20 \%$ in Vladivostok. Average long-term (20002016) disease incidence among adult population in Vladivostok city is $14,4 \%$ higher than that in the region and comprises $12,111.3$ cases per 100 th. of adults as compares to $9,759.8$ cases for 100 th. of adults in the Primorsky region [17].

Table 11. Maximum allowable concentration of airborne particles.

\begin{tabular}{|c|c|c|c|c|}
\hline \multirow{2}{*}{ Description } & \multicolumn{2}{|c|}{$\begin{array}{c}\text { Allowable limit as per WHO } \\
\text { standards [17] }\end{array}$} & \multicolumn{2}{c|}{$\begin{array}{c}\text { Allowable limit as per Russian } \\
\text { standards [18] }\end{array}$} \\
\cline { 2 - 5 } & average daily & average annual & average daily & average annual \\
\hline $\mathrm{PM} 2.5 \mu \mathrm{g} / \mathrm{m}^{3}$ & 25 & 10 & 35 & 25 \\
\hline $\mathrm{PM} 10 \mu \mathrm{g} / \mathrm{m}^{3}$ & 50 & 20 & 60 & 40 \\
\hline
\end{tabular}

Particulate emissions with exhaust gases from ship power plants in port areas can be one of the main causes for high PM10 concentration in the air as well as for the increase in the number of respiratory diseases in Vladivostok as copmpared with the other regions. Increase in freight turnover by $40 \%$ over the past three years is a good sign for the region's economy, but it also has a significant impact on the environment. The total volume of particulate emissions with exhaust gases from ship power plants in the area of the port of Vladivostok over one year is estimated as much as 64.4 tons for PM2.5 and 80.5 for PM10 under the condition that the vessels operate on $1.5 \% \mathrm{~S}$ MDO fuel. Such emissions will be significuntly reduced when the IMO regulation on the use of $0.5 \% \mathrm{~S}$ fuel for vessels comes into force on January 1,2020 . According to estimates, the use of $0.5 \% \mathrm{~S}$ fuel will be reduced by $47 \%$ for PM2.5 and by $64 \%$ for PM10, which corresponds to 30 tons/year for PM2.5 and almost 40 tons/year for PM10 in the port area of Vladivostok city.

The negative impact of emissions from ship power plants on the port environment is reflected not only in the contribution of the mass of particles from ships to the total mass concentration of particles in the region's atmosphere (up to $15 \%$ [19]), but also in the toxicity of particles emitted by ship power plants. Heavy fuel oil, the main fuel for marine engines, contains $\mathrm{V}, \mathrm{Ni}, \mathrm{S}$ ions, which makes particles in the exhaust gases of ship power plants potentially more harmful than those produced from other sources that operate on lighter hydrocarbon fuels such as gasoline or natural gas [20]. In 2007, Kuokka et al. conducted a chemical analysis of atmospheric aerosols between Moscow and Vladivostok. The result showed that the concentrations of $\mathrm{V}, \mathrm{Ni}$ and $\mathrm{SO}_{4}{ }^{2-}$ ion in $\mathrm{PM} 2.5$ were rather high within 500 $\mathrm{km}$ from Vladivostok as compared to the other regions. As of October 10, 2005, the concentration of $\mathrm{V}$, Ni and $\mathrm{SO}_{4}{ }^{2-}$ ion comprised $3 \mathrm{ng} / \mathrm{m}^{3}, 8 \mathrm{ng} / \mathrm{m}^{3}, 1.87 \mu \mathrm{g} / \mathrm{m}^{3}$, respectively. On October 11, 2005, these concentrations of $\mathrm{V}$ and $\mathrm{Ni}$ were about $1 \mathrm{ng} / \mathrm{m}^{3}$, but the concentration of $\mathrm{SO}_{4}{ }^{2-}$ ion in $\mathrm{PM} 2.5$ reached $10.719 \mu \mathrm{g} / \mathrm{m}^{3}$, which was the highest value among the measurement results [21]. Based on a simple model developed by Agrawal et al. in 2009 [22], the contribution of ship emissions to primary PM2.5 in the area of Vladivostok was estimated as $0.377 \mu \mathrm{g} / \mathrm{m}^{3}$ as of October 10,2005 and as $0.126 \mu \mathrm{g} / \mathrm{m}^{3}$ as of October 11 , 2005. 


\section{Conclusions}

The above results and analysis show that the mass concentration of PM10 at eight measurement points exceeds the allowable limit as per WHO standards (by more than 1.5 times). Concentration of particles varied depending on the season of the year. In five out of eight points the concentration of particles in winter was higher, about $1.2-2.2$ times for PM2.5 and 1.7 - 3.8 times for PM10, as compared with the concentration in summer. The total mass of particles emitted from vessels in the port area depends on sulfur content in fuel. When all vessels operated on $1.5 \% \mathrm{~S}$ MDO, the total mass of particles comprised about 80.4 tons/year for PM10 and 60.5 tons/year for PM 2.5. The total mass of particles will decrease by $47 \%$ or 30 tons/year for PM2.5 and by $64 \%$ or 40 tons/year for PM10 with IMO regulation on sulfur content in fuel $(0.5 \%)$ that will become effective as of January 1,2020 . The contribution of primary PM2.5 particles emitted from ships in the area of Vladivostok was estimated to be higher than $0.126 \mu \mathrm{g} / \mathrm{m}^{3}$. The negative impact of exhaust gases from ships on the environment of the region may be one of the main reasons that the disease incidence among adult population of Vladivostok city is $14.4 \%$ higher than the regional value.

\section{References}

1. WHO. Ambient air pollution: A global assessment of exposure and burden of disease. WHO Press, World Health Organization. Geneva, Switzerland, 2016.

2. S. Lawrence, Sokhi R., Ravindra K. Quantification of vehicle fleet PM10 particulate matter emission factors from exhaust and non-exhaust sources using tunnel measurement techniques. Environmental Pollution. 2016;210:419-428.

3. J.M. Wang, Jeong C.H., Zimmerman N., Healy R.M., Evans G.J. Real world vehicle fleet emission factors: Seasonal and diurnal variations in traffic related air pollutant. Atmospheric Environment. 2018;184:77-86.

4. A. Friedrich, Heinen F., Kamakaté F., Kodjak D. Air Pollution and Greenhouse Gas Emissions from Ocean-going Ships: Impacts, Mitigation Options and Opportunities for Managing Growth. The International Council on Clean Transportation. 2007(153):310. DOI: $10.1080 / 07266472.2007 .10878845$

5. A. Miola, Ciuffo B., Giovine E., Marra M. Regulating air emissions from ships: the state of the art on methodologies, technologies and policy options. JRC Reference Reports. Luxembourg, 2010.

6. K. Golokhvast, Agoshkov A., Agoshkov A., Kupriyanov A. N., Kupriyanov A. N., Manyakov Yu. A. Ecological characteristics of air suspensions at coal mining facilities: from production to combustion. 4, pp. 87-90, 2017.

7. K. Y. Kirichenko, A. I. Agoshkov, V. A. Drozd, Gridasov, A. V., Kholodov A. S., Kobylyakov S. P., Kosanov D. Yu., Zakharenko A. M., Karamzov A. A., Szymanski, S. R., A. K. welding Characteristics of smoke particles produced during arc welding with coated electrodes of different// Scientific reports. 8, 2018.

8. V. Chernyshev, Zakharenko A., Ugai S., Hien T., Khai L., Olesik S., Kholodov A., Zubko E., Kokkinakis M., Burykina T., Stratidakis A., Mezhuev Yu. O., Sarigiannis D., Tsatsakis A., Golokhvast K., Morphological and chemical composition of solid particles in bus exhaust gases// Toxicological reports, vol. 6, pp. 120-125, 2019.

9. FESO. Financial and operational results of the FESCO Transport Group for 2018. URL: https://www.fesco.ru/en/press-center/news/34269/.Cadle S.H., Mulawa P., Groblicki P., Laroo C. In-use light-duty gasoline vehicle particulate matter emissions on three driving cycles. Environmental Science and Technology. 2001;35:26-32. 
10. A.M. Jones, Harrison R.M. Estimation of the emission factors of particle number and mass fractions from traffic at a site where mean vehicle speeds vary over short distances. Atmospheric Environment. 2006;40:7125-7137.

11. Z.D. Ristovski, Morawska L., Bofinger N.D., Hitchins J. Submicrometer and supermicrometer particulate emission from spark ignition vehicles. Environmental Science and Technology. 1998:32(24):3845-3852.

12. A. Kristensson, Johansson C., Westerholm R., Swietlicki E., Gidhagen L., Wideqvist U., Vesely V. Real-world traffic emission factors of gases and particles measured in a road tunnel in Stockholm, Sweden. Atmospheric Environment. 2004;38(5):657-673.

13. Starcrest Consulting Group, LLC. Inventory of emissions at the Port of Los Angeles for calendar year 2009. Los Angeles: Technical Report, 2010.

14. S. Sosa Beatriz, Porta Andres., Lerner Jorge Esteban Colman., Noriega Roxana Banda., Massolo Laura. Risk to human health due to changes in PM10-PM2. 5 and associated PAH levels// Atmospheric Environment, 2017, vol.160, pp. 27-35.

15. S. A. Lozovskaya, Pogorelov A. R., tsitsiashvili G. sh., Rodchenkova T. V., Izergina E. V., Veremchuk L. V., Mineeva E. E., Witkin T. I., Gvozdenko T. A., Siedlecka K. A., K. S. Holocuast Regional features of formation of respiratory diseases in the South of the Russian far East Primorsky Krai// Preventive medicine, 2018.

16. Who. Atmospheric air pollution. URL: https://www.who.int/news-room/factsheets/detail/ambient-(outdoor)-air-quality-and-health.

17. MPC. Maximum permissible concentrations of pollutants in the atmospheric air of populated areas: hygienic standard. Maximum permissible concentrations (MPC) of pollutants in the atmospheric air of populated areas: hygienic standard No. 2.1.6.260410-M.: Standard, 2010. 36 p., 2010.

18. IAPH, project GEF-UNDP-IMO Glo MEEP and. Guide to Port Emissions, Guide No. 1: Estimation of Port Emissions. International Maritime Organization and International Association of Ports and Harbors (IAPH), 2018.

19. S. Huang, Hu Qingyao. Wang Hanyu., Qiao Liping., Jing Sheng'ao., Wang Hongli., Zhou Min., Shuhui Zhu., Inge Ma Shengrong Lu., Li Li Shikang Tao., Yingjie Li Dim $\mathrm{Lu}$. Coefficients of emissions of solid and gaseous compounds from a large cargo ship operated under real conditions/ / Environmental pollution, 2018, vol. 242, pp. 667-674.

20. S. Kuokka, Teinilya K., Saarnio K., Aurela M., Sillanpa M., Hillamo R., Kerminen M., Vartiainen E., Kulmala M., Skorokhod A. I., Elansky N. F., Belikov I. B. Using a moving measurement Platform for determining the chemical composition of atmospheric aerosols between Moscow and Vladivostok//Atmos-Chem-Fiz, 2007, issue 7, pp. 4739-4805.

21. H. Agrawal, Eden R., Zhang H., Katzenstein A. Primary particulate matter from ocean engines in the Southern California Air Basin// Ecological scientific technology. 2009, vol. 43, pp. 5398-5402. 